\title{
THE DYNAMIGS OF MARINE ICE SHEETS
}

\author{
By Robert H. Thomas \\ (Institute for Quaternary Studies, University of Maine at Orono, Orono, Maine 04473, \\ U.S.A.)
}

\begin{abstract}
Marine ice sheets rest on land that, for the most part, is below sea-level. Ice that flows across the grounding line, where the ice sheet becomes afloat, either calves into icebergs or forms a floating ice shelf joined to the ice sheet. At the grounding line there is a transition from ice-sheet dynamics to ice-shelf dynamics, and the creep-thinning rate in this region is very sensitive to sea depth; rising sea-level causes increased thinning-rates and grounding-line retreat, falling sea-level has the reverse effect. If the bedrock slopes down towards the centre of the ice sheet there may be only two stable modes: a freely-floating ice shelf or a marine ice sheet that extends to the edge of the continental shelf. Once started, collapse of such an ice sheet to form an ice shelf may take place extremely rapidly. Ice shelves which form in embayments of a marine ice sheet, or which are partially grounded, have a stabilizing influence since ice flowing across the grounding line has to push the ice shelf past its sides. Retreat of the grounding line tends to enlarge the ice shelf, which ultimately may become large enough to prevent excessive outflow from the ice sheet so that a new equilibrium grounding line is established; removal of the ice shelf would allow retreat to continue. During the late-Wisconsin glacial maximum there may have been marine ice sheets in the northern hemisphere but the only current example is the West Antarctic ice sheet. This is buttressed by the Ross and Ronne Ice Shelves, and if climatic warming were to prohibit the existence of these ice shelves then the ice sheet would collapse. Field observations suggest that, at present, the ice sheet may be advancing into parts of the Ross Ice Shelf. Such advance, however, would not ensure the security of the ice sheet since ice streams that drain to the north appear to flow directly into the sea with little or no ice shelf to buttress them. If these ice streams do not flow over a sufficiently high bedrock sill then they provide the most likely avenues for ice-sheet retreat.
\end{abstract}

RÉsumé. La dynamique des calottes glaciaires marines. Les calottes glaciaires marines resposent sur un sol qui, pour la plus grande part est en dessous du niveau de la mer. La glace qui s'écoule à travers la ligne de décollement, lorsque la glace commence à flotter, soit vêle en icebergs soit forme une couverture de glace qui se raccorde à la calotte glaciaire. A la ligne de décollement il y a une transition de la dynamique des calottes à celle des plateformes de glace, et l'amincissement dû au mouvement des glaces dans cette région est très sensible à la profondeur de la mer; si le niveau marin s'élève, la vitesse de l'amincissement s'accroît et la ligne de décollement recule, une baisse du niveau des mers a l'effet inverse. Si la pente du lit rocheux descend vers le centre de la calotte glaciaire il ne peut y avoir que deux états stables: une plateforme flottant librement ou une calotte glaciaire marine qui s'étend jusqu'à la limite du plateau continental. Une fois entamée, la rupture d'une telle calotte glaciaire pour former une plateforme peut se produire extrêmement vite. Les plateformes qui se forment dans les golfes d'une calotte glaciaire marine ou celles qui reposant partiellement sur le roc ont une influence stabilisatrice puisque la glace qui se met à flotter en traversant la la ligne de décollement doit pousser la plateforme au-delà de ses limites. Le recul de la ligne de décollement tend à agrandir la plateforme qui peut finalement devenir assez vaste pour empêcher une émission excessive de glace par la calotte de sorte qu'il s'établit un nouvel équilibre de la ligne de décollement; l'enlèvement de la plateforme permettant au recul de la ligne de continuer. Au cours du dernier maximum glaciaire du Wisconsin il a pu y avoir une calotte glaciaire marine dans l'hémisphère Nord, mais le seul exemple classique est la calotte glaciaire de l'Ouest Antarctique. Celle-ci est verrouillée par les plateformes de Ross et de Ronne et si un réchauffement climatique venait à empêcher l'existence de ces plateformes, la calotte glaciaire s'effonderrait. Les observations de terrain font penser que, pour le moment, la calotte peut être en train d'avancer en certaines parties du Ross Ice Shelf, une telle avance, cependant, n'assurerait pas la permanence de la calotte puisque le courant de glace qui la draine vers le Nord semble s'écouler directement dans la mer avec peu ou pas de plateforme pour la bloquer. Si ces courants de glace ne coulent pas sur un seuil du lit rocheux suffisamment haut, ils donnent les plus grandes chances à un retrait de la calotte glaciaire.

Zusammenfassung. Die Dynamik mariner Eisdecken. Marine Eisdecken sitzen auf Land auf, das grösstenteils unter dem Meeresspiegel liegt. Eis, das über die Aufsetzlinie fliesst, wo die Eisdecke schwimmend wird, kalbt entweder zu Eisbergen oder bildet ein schwimmendes, mit der Eisdecke verbundenes Schelfeis. An der Aufsetzlinie findet der Übergang von der Eisdecken- zur Schelfeisdynamik statt. Die Ausdünnungsrate in diesem Gebiet reagiert sehr empfindlich auf die Wassertiefe; steigender Meeresspiegel verursacht erhöhte Ausdünnungsraten und Rückzug der Aufsetzlinie; fallender Meeresspiegel hat die umgekehrte Wirkung. Wenn das Felsbett gegen das Zentrum der Eisdecke abfällt, dürften nur zwei stabile Formen vorkommen: ein frei schwimmendes Schelfeis oder eine marine Eisdecke, die sich bis an den Rand des Kontinentalschelfes erstreckt. Der Zusammenbruch einer solchen Eisdecke in ein Schelfeis dürfte sehr schnell stattfinden, wenn er einmal begonnen hat. Schelfeise, die sich in Buchten von marinen Eisdecken bilden oder die teilweise aufsitzen, haben einen stabilisierenden Einfluss, da Eis, das über der Aufsetzlinie fliesst, das Schelfeis zur Seite drücken muss. Ein Rückzug der Aufsetzlinie hat eine Vergrösserung des Schelfeises zur Folge, das letztlich so stark anwachsen kann, dass es ein übermässiges Ausfliessen der Eisdecke verhindert und dadurch eine neue Gleichgewichtslage der Aufsetzlinie herstellt; bei einem Verschwinden des Schelfeises würde sich der Rückzug fortsetzen. Während des Maximus der späten Wisconsin-Eiszeit dürften marine Eisdecken 
auf der Nordhalbkugel existiert haben; das einzige gegenwärtige Beispiel ist jedoch der westantarktische Eisschild. Er wird durch das Ross- und Ronne-Schelfeis gestützt und würde zusammenbrechen, wenn Erwärmung des Klimas die Existenz dieser Schelfeise verhindern würde. Feldbeobachtungen deuten darauf hin, dass der Eisschild derzeit in Teile des Ross-Schelfeises vorstösst. Solch ein Vorstoss würde jedoch die Sicherheit des Eisschildes nicht garantieren, da Eisströme, die nach Norden abfliessen, direkt ins Meer zu fliessen scheinen, mit keiner oder nur geringer Abstützung durch Schelfeis. Wenn diese Eisströme nicht über eine genügend hohe Schwelle im Felsbett fliessen müssen, dann stellen sie die wahrscheinlichsten Strassen für einen Rückzug des Eisschildes dar.

\section{INTRODUCTION}

In Antarctica today there are three types of ice sheet. There is a "terrestrial ice sheet" in East Antarctica resting on land which, for the most part, is above sea-level and which would be well above sea-level if the ice sheet were removed and isostatic recovery were to take place. In contrast, most of the land beneath the West Antarctic ice sheet is well below sea-level and would remain so even after removal of the ice; the overlying ice sheet here is known as a "marine ice sheet". Finally, there are the ice shelves, which form where ice flows onto the sea, which occupy the great embayments in the Antarctic coastline, and which serve to smooth the outline of the continent. The East Antarctic ice sheet is the most stable of these; removal of the others would have only a peripheral effect on it and would lead to a high probability of ice-sheet growth, since moist air would be allowed access to a major portion of the ice sheet which today is separated from the sea. Although an ice shelf is to some extent nourished by snow falling on its surface, the large Antarctic ice shelves probably could not exist without a supply of ice from the grounded ice sheets; local snow accumulation alone would not be

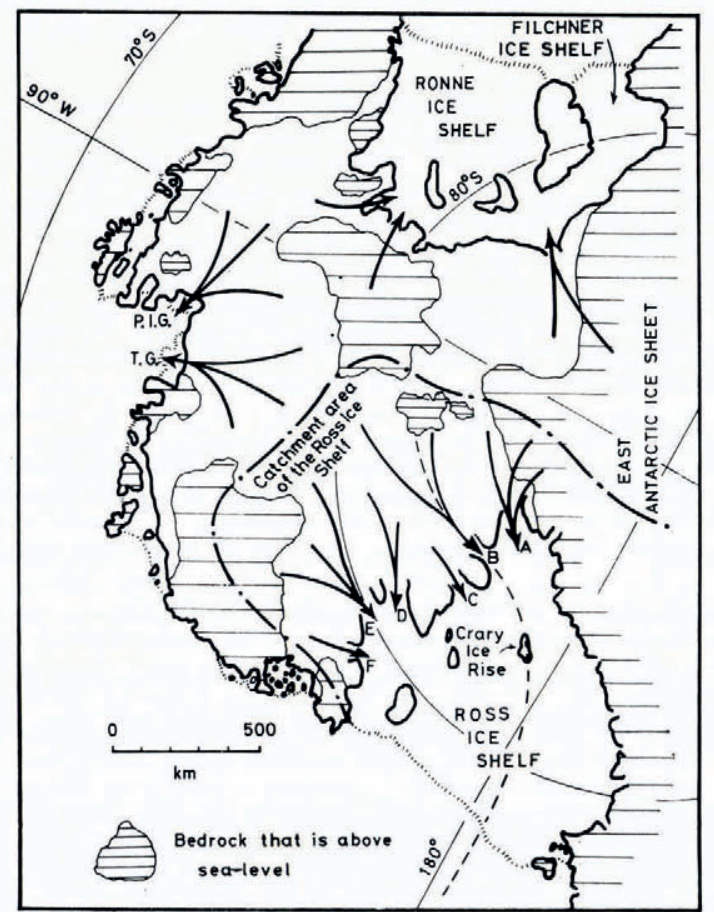

Fig. I. West Antarctica, showing the areas of bedrock that are above sea-level. The arrows represent ice streams that drain the ice sheet. Most of the ice that flows into the Ross Ice Shelf from West Antarctica drains through ice streams B, D, and E. Pine Island Glacier (P.I.G.) and Thwaites Glacier (T.G.) carry most of the ice that drains northward. These glaciers appear to be relatively unprotected by bounded or partially grounded ice shelves. A vertical section taken along the broken line through ice stream $B$ and the Ross Ice Shelf is shown in Figure 4. 
sufficient to balance loss by bottom melting. Despite this, ice shelves are not merely peripheral features; without their buttressing effect the West Antarctic ice sheet could not exist.

The marine ice sheet in West Antarctica (Fig. I) flows west into the Ross Ice Shelf, east into the Ronne Ice Shelf, and north into several small ice shelves that fringe the coast and are pinned by small ice rises. The bedrock beneath the grounding line between the ice shelves and West Antarctica is generally rather flat, without any sills or steps to provide a stable grounding-line position. This means that the position of the grounding line is very susceptible to changes in either ice thickness or sea-level. The ice thickness is controlled to some extent by the damming effect of the ice shelf, and removal of the ice shelf would allow the grounding line to retreat. Indeed, Mercer (1968) suggested that the present-day West Antarctic ice sheet would collapse almost completely if climatic conditions were not suited to the existence of ice shelves. He proposed that this may have happened during the Sangamon Interglacial, I 20 ooo years ago, when sea-level was approximately $5 \mathrm{~m}$ higher than it is today. Because ice shelves exist at sea-level they are particularly susceptible to changes in climate, and Mercer (1978) warns of the possibility that the "greenhouse effect" from man-made carbon dioxide may cause destruction of the ice shelves and collapse of the West Antarctic ice sheet. Questions raised by this possibility will be discussed in a later section. In addition to helping us to predict ice-sheet response to possible changes in climate, an understanding of marine-ice-sheet dynamics may provide valuable insights into past glacial epochs since it appears likely that large portions of the Pleistocene ice sheets rested on rock which was below sea-level (Hughes and others, 1977).

The aim of this paper is to examine the various factors that affect the stability of a marine ice sheet, and to explore possible feedback effects which may influence the rate of growth or decay of the ice sheet. The fundamental requirement for a marine ice sheet is that the ice sheet becomes afloat at its edge, thus, the state of equilibrium of the ice sheet is dependent on conditions in this region. Attempts have been made elsewhere to derive equations for the thickness and migration-rate of ice at the grounding line (Weertman, 1974; Thomas, 1977; Thomas and Bentley, $1978[\mathrm{~b}]$ ), and I shall not repeat them here. Instead I shall try to provide a description of the physical significance of these equations and the relative importance of their component parts. I shall also discuss the state of equilibrium of the West Antarctic ice sheet and its likely response to rapid ablation of the ice shelves.

\section{THE GROUNDING LINE}

Ice that flows across the grounding line of a marine ice sheet either calves to become icebergs or forms a floating ice shelf that is joined to the ice sheet. Ice shelves tend to form in embayments or where there are sufficient shoals to pin the ice shelf. For an ice sheet that is in equilibrium, ice movement across the grounding line is balanced by accumulation over the ice sheet. Excessive snowfall causes the ice sheet to thicken and the grounding line to advance. Then, if advance takes place over a shoaling seabed, creep-thinning rates decrease so that advance may continue until the grounding line reaches the edge of the continental shelf. Conversely, if the ice at the grounding line is growing thinner, the ice sheet retreats and, for retreat over a bed that slopes downwards towards the centre of the ice sheet, the creepthinning rate increases and the ice sheet becomes more and more unstable. Under these conditions the ice sheet will collapse completely unless there is a sufficiently high bedrock sill over which the grounding line can achieve equilibrium.

For an ice sheet that flows into a bounded ice shelf or into an ice shelf that contains grounded ice rises, shear between the ice shelf and its sides and compressive stresses up-stream of the ice rises result in a back-pressure at the grounding line which can be sufficient to reduce creep-thinning rates almost to zero (Fig. 2). The grounding line is then able to achieve a new equilibrium position, with the ice shelf acting as a valve to control drainage from the ice sheet. This appears to be the situation that exists today in West Antarctica. 


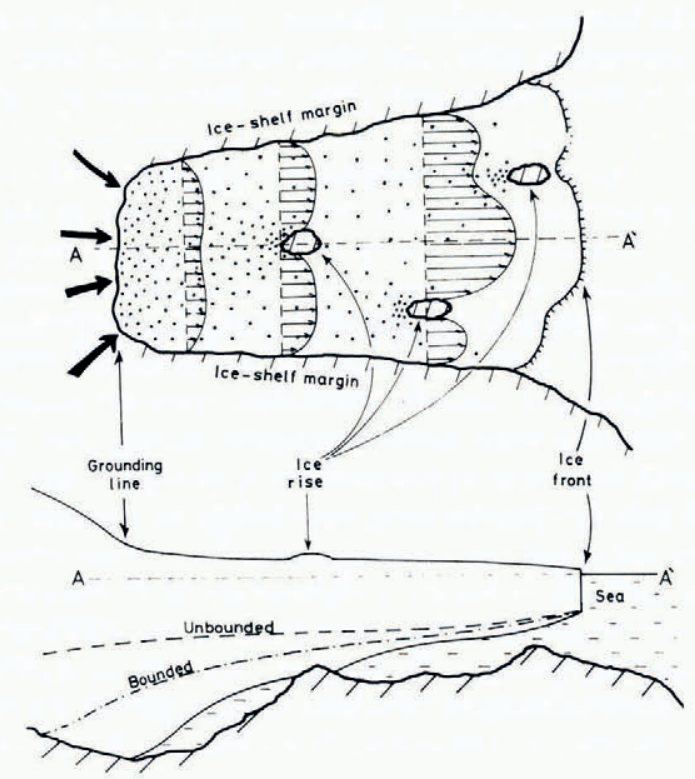

Fig. 2. A bounded ice shelf with ice rises. Velocity profiles are shown for three sections across the ice shelf. The stippling indicates the presence of a back-pressure exerted on the ice shelf by its margins and ice rises. The intensity of the stippling gives an indication of the relative magnitude of the back-pressure. Three bottom profiles are shown: the solid line is for the bounded ice shelf with ice rises and the others are for bounded and unbounded ice shelves without ice rises. The position of the grounding line is strongly dependent on the type of ice shelf that forms.

Most of the drainage from West Antarctica is through large ice streams (Rose, in press) which move principally by sliding along bedrock troughs. Between the ice streams there are promontories of slow-moving ice which is probably frozen to the bed. The equilibrium state of a marine ice sheet is determined mostly by what is happening to the ice streams, and these may not advance or retreat in unison. I shall consider the stability of only one of the ice streams and I shall assume that ice-stream movement is entirely by basal sliding so that all the ice in a vertical column is moving at the same speed. The factors affecting ice thickness at the grounding line are then:

\section{Accumulation or ablation $A$}

The ice thickens in response to local snowfall or basal ice accretion, and it thins if there is surface ablation or bottom melting. In general, there is a surface accumulation of o. $1 \mathrm{~m}$ of ice per year or more on the ice streams of West Antarctica, and usually there is surface ablation on glaciers that flow between rock walls. Bottom-melting-freezing rates are probably of the order of centimetres of ice per year.

\section{Advection $D$}

This is the transfer across the grounding line of ice from up-stream, and its magnitude is determined by the total up-stream accumulation-rate. Numerically, it is the product of thickness slope measured in the up-stream direction and ice velocity. Generally, $D$ is positive and, if the ice is moving fast, it can be very large.

Creep of the ice $C$

This is the product of ice thickness and the vertical creep-rate. Usually ice at the grounding line tends to thin by creep so that $C$ is negative. If the ice behaves in the same 
way as an unbounded ice shelf $C$ is approximately proportional to the fourth power of ice thickness (Weertman, 1957[a]). The equilibrium grounding-line thickness in this situation is typically about $400 \mathrm{~m}$. Significantly greater thicknesses require appropriately large values of advection thickening to balance the creep thinning. If the ice shelf to seaward of the grounding line is restricted by shear past its sides or by the presence of ice rises (Fig. 2) then the magnitude of $C$ is reduced (Thomas, I979). In this way an equilibrium groundingline thickness of $\mathrm{I}$ ooo $\mathrm{m}$ or more can be sustained, with creep-thinning rates that are very close to zero. These would increase by several orders of magnitude if the ice shelf were to be removed.

The sum of these three terms gives the net thickening-rate of ice $T$ at the grounding line:

$$
T=A+D+C \text {. }
$$

If $T$ is positive the ice is growing thicker and, since hydrostatic equilibrium must be maintained at the grounding line, there will be a tendency for the ice sheet to advance. If $T$ is negative then the grounding line retreats. Equilibrium is represented by $T=0$.

\section{STATE OF EQUILIBRIUM}

At any time it is unlikely that the thickening-rate $T$ is identically equal to zero. Equilibrium is more probably represented by minor fluctuations in $T$ that balance out over a long period, and the position of the grounding line is likely to oscillate in response to these fluctuations. Such minor variations in $T$ may be caused by random changes in the local accumulation-rate $A$ or in the advection term $D$, which itself responds to variations in accumulationrate over the ice sheet. Grounding-line migrations of this type are reversible so long as the changes in $A$ and $D$ are reversible. Thus, we may regard the equilibrium position of the grounding line to be somewhere within a zone that accommodates these minor fluctuations.

Sustained changes in any of the terms on the right-hand side of Equation (I) will result in a permanent shift of the grounding line to a new equilibrium position. For instance, a permanent increase in $A$ or $D$ may force the grounding line to advance to a new position, probably in deeper water, where the creep-thinning rate $(-C)$ increases sufficiently to set $T$ equal to zero. Conversely, a reduction in $A$ or $D$ causes the grounding line to retreat into shallower water. The rate of grounding-line migration and whether migration is stable or unstable depend on the seabed topography, the type of ice shelf that forms to seaward of the grounding line, ice movement across the grounding line, crustal warping, and sea-level changes.

\section{Seabed topography}

To highlight the effects of seabed topography I shall describe the behavior of an ice stream that either flows into an unbounded ice shelf or calves at the grounding line. If the seabed slopes down to seaward then grounding-line migration is limited and is determined by the slope of the seabed (Fig. $3 \mathrm{~A}$ ), if the seabed is steep then the migration will be very small. However, a marine ice sheet rests on large areas of continental shelf which, prior to loading, are comparatively level. After being depressed by the ice sheet the seabed generally slopes up to seaward, and advance of the grounding line is associated with a decrease in creep-thinning rate $(-C)$ so that $T$ becomes more and more positive. In this situation, advance continues to a point where the seabed slopes down into sufficiently deep water. In the extreme case this may be the edge of the continental shelf (Fig. $\left.{ }_{3} \mathrm{~B}\right)$. A retreating grounding line encounters a deeper bed and becomes more and more unstable until a sufficiently high sill is reached. 


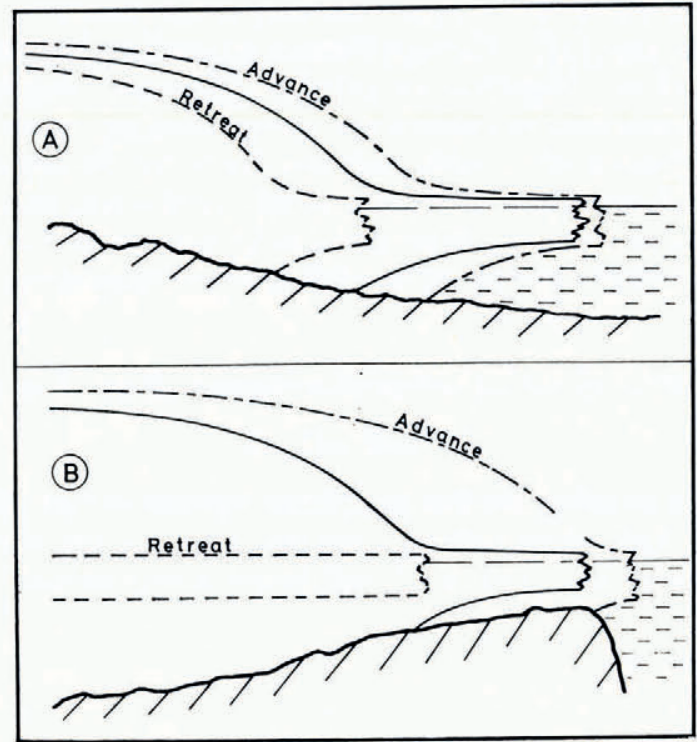

Fig. 3. Grounding-line migration. In Figure ${ }_{3} A$ the sea bed slopes down to seaward and a change in ice thickness or sea depth causes only a limited shift in the grounding-line position. If the sea bed slopes up to seaward (Fig. 3 B) and the ice sheet is not protected by a bounded or partially grounded ice shelf then there are only two stable modes. These are represented by the "advance" and "retreat" profiles in Figure ${ }_{3} B$. With a suitably bounded or pinned ice shelf, the ice sheet may adopt a stable profile that lies between these two extremes, such as that represented by the solid line. The grounding line may then migrate in response to changes in the ice shelf as well as to changes in ice thickness and sea depth.

\section{Ice shelves}

To a certain extent an ice shelf that forms to seaward of the grounding line may act as a stabilizing buffer. If the ice shelf is unrestricted so that it is no more than a floating tongue to the ice stream then the stabilizing effect is negligible. If, however, a bounded or partially grounded ice shelf forms, it exerts a back-pressure on ice at the grounding line. If the grounding line advances then the ice shelf becomes smaller and it exerts less and less back-pressure, allowing creep-thinning rates to increase and halt the advance. A retreating grounding line may be halted by back-pressure from a sufficiently large bounded ice shelf. However, the picture is further complicated by the possibility that the shear stress between the ice shelf and its sides may decrease as the ice-shelf velocity increases, due to the formation of an easy-glide fabric in ice near the ice-shelf sides (Hughes, 1977). This effect would act as a positive feedback mechanism since retreat is associated with an increase in ice velocities and advance is associated with a decrease. Moreover, ice rises that form within or disappear from the ice shelf will have a strong influence on creep-rates at the hinge line. Changes in ice-shelf dimensions following a change in climate would also affect grounding-line stability, but such changes probably take place rather slowly.

\section{Ice movement across the grounding line}

Grounding-line migration causes a marine ice sheet to adopt a new equilibrium profile, if the grounding line advances the ice sheet tends to thicken, and if there is retreat the ice sheet thins. In order to accommodate this change in thickness, the quantity of ice flowing across the grounding line, and therefore $D$ in Equation ( $\mathrm{I}$ ), increases during retreat and decreases during advance. This acts as a negative feedback mechanism slowing the rates of both retreat and advance. During very rapid retreat $D$ probably increases to several times its equilibrium value 
so that swift retreat can only be sustained if there is sufficiently rapid thinning by creep or ablation at the grounding line. As the grounding line migrates, the size of the catchment area changes so that total up-stream snow accumulation increases during advance and decreases during retreat. This provides positive feedback which tends to magnify the total distance that the grounding line migrates.

Quantitative solution of Equation (I) to give the rate of grounding-line migration (Thomas, 1977; Thomas and Bentley, r 978[b]; Hughes, 1979) involves evaluation of $D$ in terms of measurable quantities. The ice velocity can be expressed from volume conservation considerations in terms of total snow accumulation-rate, ice-sheet thickening- or thinning-rate, and grounding-line geometry. The ice-sheet thickening- or thinning-rate is related to the rate of grounding-line migration via some assumed "equilibrium" ice-sheet profile, and the grounding-line geometry can be estimated from bed topography. However, the other component of $D$, the thickness slope, involves the basal slope, which can be estimated, and the surface slope during grounding-line migration, which is unknown. Thomas (1977) and Thomas and Bentley (1978[b]) adopt a basal sliding law (Weertman, I957[b]; Kamb, r97o) which relates ice velocity to ice thickness and surface slope in order to give an estimate of surface slope at the grounding line. Clearly, this is a dubious procedure since, even if the basal-sliding law is valid, it is more appropriate to apply it further up-stream where the ice is firmly grounded. This means that the surface slope at the grounding line is probably less than the calculated value, so that actual retreat-rates are larger than the calculated ones. Hughes (1979) has modified my analysis either by assuming zero surface slope at the grounding line (and this gives very rapid retreat-rates), or by using a surface slope that is determined by an assumed value of the basal shear stress which is characteristic of the ice stream but not related to velocity. Although these various approaches show qualitative agreement, there are wide differences between calculated retreat-rates for a given ice stream. The investigation of fast glaciers near the grounding line should enable us to narrow these differences.

\section{Crustal warping and sea-level changes}

Large eustatic changes in sea-level provide the most powerful stimulus for grounding-line migration. Not only is there an immediate shift of the grounding line to preserve hydrostatic equilibrium, there also is the probability of positive feedback due to the formation or disappearance of ice rises. The latter are of particular importance since even a small ice rise can have a large damming effect at the grounding line. Indeed, even after a substantial lowering of the world sea-level, advance of the West Antarctic ice sheet into the present-day Ross Ice Shelf would almost certainly require the formation of new ice rises within an expanded ice shelf.

We have already noted that the presence of a marine ice sheet affects the topography of its bed, which tends to slope downwards towards the centre of the ice sheet. Substantial growth of an ice sheet to achieve a new equilibrium profile must take place rather slowly since it can be achieved only through retention of part of its accumulated snowfall. Thus, grounding-line advance takes place over a comparatively undepressed seabed and, to a large extent, crustal depression keeps pace with advance. On the other hand, retreat takes place as fast as ice can be transported across the grounding line, and calculations suggest that this can be very fast. In these circumstances, crustal rebound is unable to keep pace with ice-sheet collapse, and the grounding line retreats across a largely depressed bed. Rebound continues after a new equilibrium grounding line has been achieved and, if the marine ice sheet is replaced by a floating ice shelf, new ice rises will form wherever seabed shoals rise into the base of the ice shelf. The formation of these ice rises may initiate a period of grounding-line advance. In the extreme case, a self-cycling marine ice sheet may advance in response to crustal rebound and retreat in response to crustal depression, initial retreat having been 
triggered by delayed depression at the edge of the enlarged ice sheet. It is unlikely that any real ice sheet could behave in this way because eustatic changes in sea-level associated with the growth and decay of other ice sheets would control sea depth in the sensitive region near the edge of the continental shelf where a marine ice sheet establishes its advance grounding line.

\section{The stability of the West Antargtic ige sheet}

The collapse of an enlarged West Antarctic ice sheet to achieve its present grounding line with the Ross Ice Shelf has been considered by Thomas and Bentley (1978[b]). Our analysis indicated that, during the late Wisconsin, the West Antarctic ice sheet may have extended across the Ross Ice Shelf to reach a line of seabed sills that parallel the edge of the continental shelf. If it did then its collapse was probably initiated by eustatic rise in sea-level, but the ice sheet may have been in such precarious equilibrium that retreat was triggered by depression of the seabed. If no ice shelf formed during retreat then most of the West Antarctic ice sheet probably would have collapsed by about 9 000 B.P. Our results support the suggestion of Mercer ( 1968$)$ that the present-day Ross and Ronne Ice Shelves are buttressing the ice sheet, and also indicate that removal of either ice shelf would result in the collapse of the West Antarctic ice sheet within a few decades. Mercer (1978) has warned that such a collapse may be one consequence of the currently increasing levels of carbon dioxide in the atmosphere. However, even if climatic warming does become sufficient to prohibit the existence of "steadystate" ice shelves, it is probable that, during collapse of the West Antarctic ice sheet, ice shelves would continue to play some part in slowing retreat-rates. The effect of climatic warming on the ice-sheet-ice-shelf system may be summarized as follows:

I. Ice-shelf thinning due to increased melt-rates.

2. As bounded ice shelves thin, they exert less back-pressure at their up-stream grounding lines so that there is an increase in flow-rates from the ice sheet into the thinning ice shelves.

3. There is a tendency for ice-shelf thinning-rates due to melting to be balanced by increased drainage of thicker ice from the collapsing ice sheet.

In this way ice shelves will continue to exist in a state of quasi-equilibrium with the high melting- and drainage-rates, and so long as these ice shelves transmit a back-pressure to the grounding line they will slow down retreat-rates. Thus, collapse of the marine ice sheet will continue, but at a significantly slower rate than would be the case for complete removal of the ice shelf. Actual retreat-rates would depend critically on how many ice rises remain within the modified ice shelf, and on whether increased flow-rates are associated with progressive softening of ice along the sides of the ice shelf. Preliminary calculations (Thomas and others, I979) suggest that, even if the " $\mathrm{CO}_{2}$ greenhouse" effect caused ablation-rates to increase by several metres per year, the collapse of the West Antarctic ice sheet would take more than 200 years. This estimate represents a minimum since it takes no account of the time taken, first for the climate to respond to increased levels of $\mathrm{CO}_{2}$, and second for the ocean to respond to a changing climate. The ocean response is of particular importance because most of the ablation is likely to take place by bottom melting.

There is considerable disagreement concerning the current state of equilibrium of the West Antarctic ice sheet. Hughes (1975) suggested that the ice sheet may be collapsing, and measurements of surface strain-rate that were made near the ice-sheet summit have been interpreted as indicating thinning of perhaps a few centimetres per year (Whillans, 1973, 1977; Hughes, 1973; Thomas, 1976). There is poor agreement between the various estimates of thinning-rate because of lack of information on the behavior of deep ice, and errors are difficult to assess since the result is rather sensitive to errors in the strain-rate measured perpendicular to the flow direction. However, if thinning is taking place it may represent a 
delayed response of the summit to Holocene retreat of the ice-sheet margins (Thomas, 1976). If this is the case then the West Antarctic ice sheet could be slumping to cover a larger area, but with a lower summit elevation, in an attempt to achieve a new equilibrium profile. This model is consistent with the observation of current thickening in the south-east corner of the Ross Ice Shelf (Thomas and Bentley, I978[a]). Whillans (1976) was led to the conclusion that evidence from the spacing of internal layers revealed by radio echo-sounding implies that the summit of the ice sheet has been in equilibrium for about 30 ooo years. This is, however, suspect since the evidence is also consistent with uniform thinning near the summit. A thinning which is approximately uniform is precisely the delayed response we might expect to find as a result of earlier retreat of the ice-sheet margins. Clearly, more data are required before this question can be answered. Perhaps the least ambiguous results could be obtained from a strain network covering the entire summit region. Such an experiment could best be made using techniques that are currently available involving survey equipment mounted in either an aeroplane or a satellite.

Figure 4 shows a section through ice stream B and across the Ross Ice Shelf. Observations suggest that the ice shelf between the grounding line and the Crary Ice Rise is growing thicker by one metre every three years (Thomas and Bentley, 1978[a]). If these high thickeningrates were sustained then this entire area would run aground within the next 300 years. The large areas of comparatively flat grounded ice that would form must ultimately offer increased resistance to flow of ice into the ice shelf, so that ice velocities would decrease and ice would pile up in the lower reaches of ice stream B. This process may explain the apparent anomaly of ice stream C, which, from radio echo-sounding evidence (Rose, r979), should be a very active ice stream. Comparatively simple field experiments in the lower reaches of the West Antarctic ice streams should indicate whether widespread advance is taking place.

Along parts of the northern coast of the West Antarctic ice sheet, ice streams appear to flow directly into the sea with little or no ice shelf to buttress them (Fig. I). It is in this region that partial collapse of the ice sheet may be taking place. If the ice streams do not flow over a sufficiently high bedrock sill, then the grounding lines may retreat a significant distance into the heart of West Antarctica. The Thwaites and Pine Island glaciers are the most likely exits for such a collapse (Hughes, 1977); their catchment areas lie over large areas of bedrock that are more than I $000 \mathrm{~m}$ below sea-level. Unfortunately, there is no information on bedrock topography near their grounding lines. However, Equation (I) can be solved to give the maximum depth of a bedrock sill that could support an equilibrium ice sheet, in terms of total up-stream accumulation, the width of the grounding line, and the ice flow-law and sliding-law

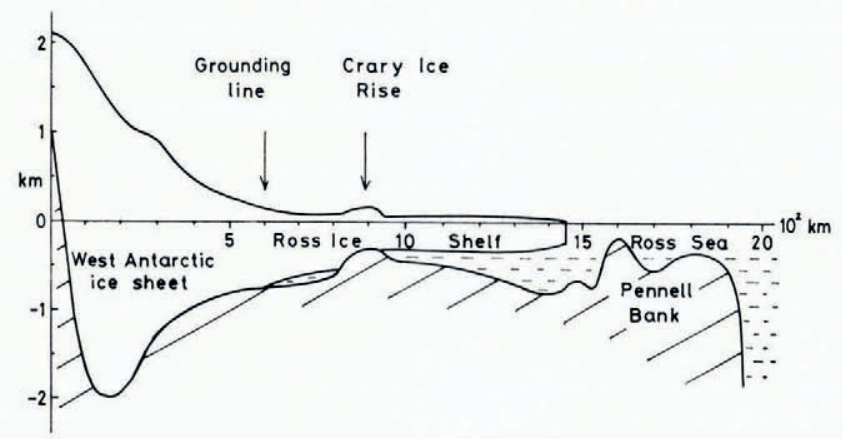

Fig. 4. A section through the West Antarctic ice sheet and across the Ross Ice Shelf (see Fig. I). The bedrock topography is similar to that shown in Figure $3 B$, and the grounding line is maintained in its present position by back-pressure that is exerted on the Ross Ice Shelf by its sides and by the Crary Ice Rise. Only a very small thickening would be necessary for the ice sheet to advance to cover Crary Ice Rise. Thereafter, further advance would require grounding of the ice shelf on the shoals of Pennell Bank. 
parameters (equation (A $\mathrm{A}_{3}$ ) from Thomas and Bentley, $1978[\mathrm{~b}]$ ). Using available measurements of snow accumulation-rate (Bull, I 97 I), estimates of grounding-line width from satellite photographs, and the flow-law and sliding-law parameters from Thomas and Bentley (1978[b]) I have estimated the equilibrium sill depth below sea-level $b^{\star}$ for each of these glaciers. For the Thwaites Glacier, $b^{\star}$ lies between 400 and $550 \mathrm{~m}$, with an associated ice velocity across the grounding line of approximately three kilometres per year. For Pine Island Glacier I have calculated two values of $b^{\star}$ corresponding to the presence or absence of a small bounded ice shelf which may exist, depending on the precise position of the grounding line. If the ice shelf exists, $b^{\star}$ lies between 520 and $610 \mathrm{~m}$, and if it does not exist $b^{\star}$ lies between 410 and $55^{\circ} \mathrm{m}$. Associated ice velocities at the grounding line are approximately two and three kilometres per year respectively. If the actual sill depth turns out to be greater than $b^{\star}$ for either of these glaciers, then the glacier is unstable and there is a high risk of major icesheet collapse within its catchment area. This would affect neighbouring glaciers, and it could trigger collapse of a large part of the West Antarctic ice sheet.

The range of values that $I$ have given for $b^{\star}$ correspond to a wide range of basal-sliding laws and, although there are bound to be large errors in the assumed values of other parameters, we should note that, approximately,

$$
\left.b^{\star} \propto \text { (total up-stream accumulation-rate/grounding-line width) }\right)^{\frac{1}{4}} .
$$

The value of $b^{\star}$ is most influenced by the creep behavior of ice at the grounding line and, if the assumption that this can be described by ice-shelf dynamics is correct, these values of the equilibrium sill depth should provide a good first approximation. I would suggest that measurement of actual sill depth should take a high priority in future radio echo-sounding programmes. The result would indicate whether additional field work is warranted in order to detect whether or not the ice sheet is collapsing through these glaciers.

\section{AGKNowledgements}

This work was partially supported by National Science Foundation grant DPP 76-23047 Aor, and it was completed while I was a Visiting Scholar at the Scott Polar Research Institute.

\section{REFERENGES}

Bull, C. B. B. 1971. Snow accumulation in Antarctica. (In Quam, L. O., ed. Research in the Antarctic. Washington, D.C., American Association for the Advancement of Science, p. 367-421. (Publication No. 93.))

Hughes, T. J. 1973. Is the West Antarctic ice sheet disintegrating? Journal of Geophysical Research, Vol. 78, No. 33 , p. 7884-9 10.

Hughes, T. J. 1975. The West Antarctic ice sheet : instability, disintegration, and initiation of ice ages. Reviews of Geophysics and Space Physics, Vol. 13 , No. 4, p. 502-26.

Hughes, T. J. 1977. West Antarctic ice streams. Reviews of Geophysics and Space Physics, Vol. 15, No. I, p. I-46.

Hughes, T. J. 1979. Reconstruction and disintegration of ice sheets for the CLIMAP 18 ooo and 125 ooo years B.P. experiments: theory. Fournal of Glaciology, Vol. 24, No. 90, p. 493-95.

Hughes, T. J., and others. I977. Was there a late-Würm Arctic ice sheet? [By] T. J. Hughes and G. H. Denton, M. G. Grosswald [i.e. Grosval'd]. Nature, Vol. 266, No. 5603, p. 596-6o2.

Kamb, W. B. 1970. Sliding motion of glaciers: theory and observation. Reviews of Geophysics and Space Physics, Vol. 8, No. 4, p. $673-728$.

Mercer, J. H. I968. Antarctic ice and Sangamon sea level. Union de Géodésie et Géophysique Internationale. Association Internationale d'Hydrologie Scientifique. Assemblée générale de Berne, 25 sept.-7 oct. 1967. [Commission des Neiges et Glaces.] Rapports et discussions, p. 217-25. (Publication No. 79 de l'Association Internationale d'Hydrologie Scientifique.)

Mercer, J. H. 1978. West Antarctic ice sheet and $\mathrm{CO}_{2}$ greenhouse effect: a threat of disaster. Nature, Vol. 27I, No. 5643 , p. $321-25$.

Rose, K. E. In press. Radio echo studies of bedrock in Marie Byrd Land, Antarctica. (In Craddock, C., ed. Antarctic geoscience. Proceedings of the third Symposium on Antarctic Geology and Geophysics, Madison, 22-27 August, 1977. Madison, University of Wisconsin Press. 
Thomas, R. H. 1976. Thickening of the Ross Ice Shelf and equilibrium state of the West Antarctic ice sheet. Nature, Vol. 259 , No. 5540 , p. $180-83$.

Thomas, R. H. 1977 . Calving-bay dynamics and ice-sheet retreat up the St. Lawrence Valley system. Géographie Physique Quaternaire, Vol. 31, Nos. 3-4, p. 347-56.

Thomas, R. H. 1979. Ice shelves: a review. Journal of Glaciology, Vol. 24, No. 9o, p. 273-86.

Thomas, R. H., and Bentley, C. R. 1978[a]. The equilibrium state of the eastern half of the Ross Ice Shelf. Fournal of Glaciology, Vol. 20, No. 84, p. 509-18.

Thomas, R. H., and Bentley, C. R. 1978[b]. A model for Holocene retreat of the West Antarctic ice sheet. Quaternary Research, Vol. 10, No. 2, p. $150-70$.

Thomas, R. H., and others. 1979. Effect of climatic warming on the West Antarctic ice sheet, by R. H. Thomas, T. J. O. Sanderson, and K. E. Rose. Nature, Vol. 277 , No. 5695, p. $355-58$.

Weertman, J. 1957[a]. Deformation of floating ice shelves. Fournal of Glaciology, Vol. 3, No. 21, p. 38-42.

Weertman, J. $1957[\mathrm{~b}]$. On the sliding of glaciers. Fournal of Glaciology, Vol. 3, No. 21, p. 33-38.

Weertman, J. 1974. Stability of the junction of an ice sheet and an ice shelf. Fournal of Glaciology, Vol. 13, No. 3, p. $3^{-1} \mathrm{I}$.

Whillans, I. M. 1973. State of equilibrium of the West Antarctic inland ice sheet. Science, Vol. 182, No. 41 I I, p. $476-79$.

Whillans, I. M. 1976. Radio-echo layers and the recent stability of the West Antarctic ice sheet. Nature, Vol. 264, No. $55^{82}$, p. $152-55$.

Whillans, I. M. I977. The equation of continuity and its application to the ice sheet near "Byrd" Station, Antarctica. Fournal of Glaciology, Vol. 18, No. 8o, p. 359-71.

\section{DISGUSSION}

W. F. BuDD: Instead of your proposed back-pressure term $P$ is it not also possible to have a net tension force at the grounding line especially in the case of increasing velocities in the flow direction across the grounding line?

R. H. Thомas: Yes. In general, there is a tensile stress at the top of the ice shelf in the direction of flow, and the ice-shelf velocity increases towards the ice front. However the "back pressure" $P$ refers to the restraining effect of the ice-shelf sides and of ice rises, which exert a force acting up-stream. This reduces the tensile stress at the surface, which essentially is due to the weight of ice above sea-level. In general, the ice thickness increases as $P$ increases so that the net longitudinal stress at the surface remains tensile.

O. ORHeim: You suggest that instant removal of the Ross Ice Shelf will cause rapid collapse of part of the ice sheet through speeded-up drainage by accelerated ice streams. I will maintain that this is not realistic, because these ice streams will again run aground on ice rises and slow down, sea ice will form between the ice streams, and this will increase the ice shelf cover.

Thomas: I agree that instant removal of the ice shelf is unrealistic, and I have included the calculation of retreat rates for the case of no ice-shelf formation solely to provide the limiting value; I do not propose this as a realistic model. Elsewhere (Thomas and others, I979), I calculate retreat rates associated with increased ice-shelf ablation-rates and it appears that, even with massive ablation, the ice shelves would continue to buffer ice-sheet collapse. 